\title{
DINOFLAGELLATE CYST DISTRIBUTION DURING THE MIDDLE EOCENE IN THE DRAKE PASSAGE AREA: PALEOCEANOGRAPHIC IMPLICATIONS
}

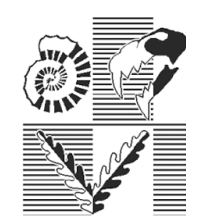

\author{
M. SOL GONZÁLEZ ESTEBENET ${ }^{1}$, G. RAQUEL GUERSTEIN ${ }^{1}$ AND MARTA I. ALPERIN²
}

${ }^{1}$ Instituto Geológico del Sur, Departamento de Geología, Universidad Nacional del Sur, San Juan 670, B8000ICN, Bahía Blanca, Argentina. sol.gonzalezestebenet@uns.edu.ar; raquel.guerstein@uns.edu.ar

${ }^{2}$ Facultad de Ciencias Naturales y Museo, Universidad Nacional de La Plata. Calle 64 s/n e/ Bv. 120 y Diag. 113, 1900, La Plata, Argentina. marta.alperin@gmail.com

\begin{abstract}
The middle-late Eocene (45-36 Ma) dinoflagellate cyst distribution in high latitudes of the Southern Hemisphere has been explained by a surface ocean circulation pattern characterized by extensive subpolar gyres around Antarctica. Based on global paleoclimate models it has been proposed that these surface ocean gyres might favored the development of an Antarctic-endemic dinoflagellate cyst assemblage, which was consistently abundant until the end of the Eocene. During the late Eocene the deepening of the Tasman Gateway and the Drake Passage would have generated a circumpolar water flow responsible for the disruption of the local gyre system and the subsequent extinction of the endemic assemblage. Some authors have recently suggested that during the middle Eocene shallow water flows had already developed through incipient openings of the Tasman Gateway and the Drake Passage. In this review we have compared the middle Eocene dinoflagellate cysts assemblages dominated by the Antarctic-endemic species from localities of the Drake Passage area and performed a multivariate analysis to evaluate this hypothesis. Our results point out a clear differentiation between localities to the north and south of what now is the Drake Passage. While localities from the Antarctic Peninsula and Scotia Sea would had been affected by Antarctic surface waters, the Austral Basin would had been flooded by Antarctic waters together with Pacific waterflows developed through an incipient Drake Passage during the middle Eocene.
\end{abstract}

Key words. Dinoflagellate cysts. Middle Eocene. Drake Passage. Early opening.

Resumen. DISTRIBUCIÓN DE QUISTES DE DINOFLAGELADOS DURANTE EL EOCENO MEDIO EN EL ÁREA DEL PASAJE DE DRAKE: IMPLICANCIAS PALEOCEANOGRÁFICAS. La distribución de quistes de dinoflagelados del Eoceno medio-tardío (45-36 $\mathrm{Ma}$ ) en altas latitudes del Hemisferio Sur ha sido explicada por un patrón de circulación oceánica superficial caracterizado por amplios giros subpolares alrededor de Antártida. Sobre la base de modelos paleoclimáticos globales se ha propuesto que dichos giros podrían haber favorecido el desarrollo de una asociación de quistes de dinoflagelados endémica-Antártica, la que habría prevalecido hasta el final del Eoceno. Durante el Oligoceno la profundización del Conducto de Tasmania y el Pasaje de Drake habrían generado un flujo de agua circumpolar responsable de la disrupción del sistema de giros y de la subsecuente extinción de la asociación endémica. Recientemente algunos autores han sugerido que durante el Eoceno medio ya se habrían desarrollado flujos de aguas poco profundas a través de aperturas incipientes del Conducto de Tasmania y el Pasaje de Drake. En este trabajo se compararon las asociaciones de quistes de dinoflagelados dominadas por la asociación endémica Antártica de localidades del área del Pasaje de Drake y se realizó un análisis multivariado para evaluar esta hipótesis. Los resultados obtenidos señalan una clara separación entre las localidades al norte y al sur de lo que hoy es el Pasaje de Drake. Mientras que la Península Antártica y el Mar de Scotia habrían sido afectadas por aguas superficiales originadas en Antártida, la Cuenca Austral habría sido inundada por aguas antárticas junto con flujos de agua del Pacífico desarrollados a través de un incipiente Pasaje de Drake durante el Eoceno medio.

Palabras clave. Quistes de dinoflagelados. Eoceno medio. Pasaje de Drake. Apertura temprana.

FossIL organic-walled dinoflagellate cysts are abundant in continental shelf sediments and their spatial distribution depends on the physico-chemical characteristics of the water-masses in which the dinoflagellates developed, and on past ocean circulation patterns (Sluijs et al., 2005). During the Paleogene, dinoflagellate cyst assemblages in the Southern Ocean evidenced major modifications as a consequence of the climatic and tectonic changes that occurred during this period (Stickley et al., 2004; Guerstein et al., 2010; Bijl et al., 2013a).
Paleocene and early Eocene circum-Antarctic assemblages were widely dominated by cosmopolitan early Paleogene taxa and endemic species were scarce (Bijl et al., 2011, 2013a, b). At the beginning of the middle Eocene $(-50 \mathrm{Ma})$ dinoflagellate cyst assemblages began to experience a significant change, resulting in the dominance of recorded endemic taxa in the Southern south of $45^{\circ} \mathrm{S}$ (Bijl et al., 2011). This assemblage, originally called "Transantarctic Flora” by Wrenn and Beckmann (1982), was dominated by endemic and bipolar 
taxa differing from species with cosmopolitan and tropical distributions (Lentin and Williams, 1980; Wrenn and Hart, 1988; Bijl et al., 2011, 2013a). As proposed by Huber et al. (2004), the middle-late Eocene dinoflagellate cyst distribution reflected an ocean-circulation scheme with broad clockwise gyres surrounding Antarctica. The Antarctic-endemic assemblage prevailed until the Eocene/ Oligocene transition, when the endemic species were replaced by Oligocene cosmopolitan taxa (Houben et al., 2013). The extinction of the endemic assemblage may have occurred as a result of the deepening of the Tasmanian Gateway and the Drake Passage (Sluijs et al., 2003; Stickley et al., 2004; Guerstein et al., 2008a; Houben et al., 2011, 2013). Such tectonic changes and the subsequent development of an unrestricted circumpolar waterflow during the early Oligocene would have disrupted the subpolar gyres and altered the environmental conditions that favored dinoflagellate endemism (Huber et al., 2004).

Bijl et al. (2013a) have recently calibrated dinoflagellate cyst assemblages from sediment cores drilled on the Tasman shelves with the Geomagnetic Polarity TimeScale (GPTS) of Vandenberghe et al. (2012). These authors also proposed a high-resolution Southern Pacific Ocean dinoflagellate cyst zonation for the late Palaeocene to the late Eocene (58-36 $\mathrm{Ma})$ and confirmed that the Antarctic-endemic dinoflagellate cyst assemblage was dominant during the mid to late Eocene ( - 45-39 Ma). Thus, the mid-Paleogene dinoflagellate cyst

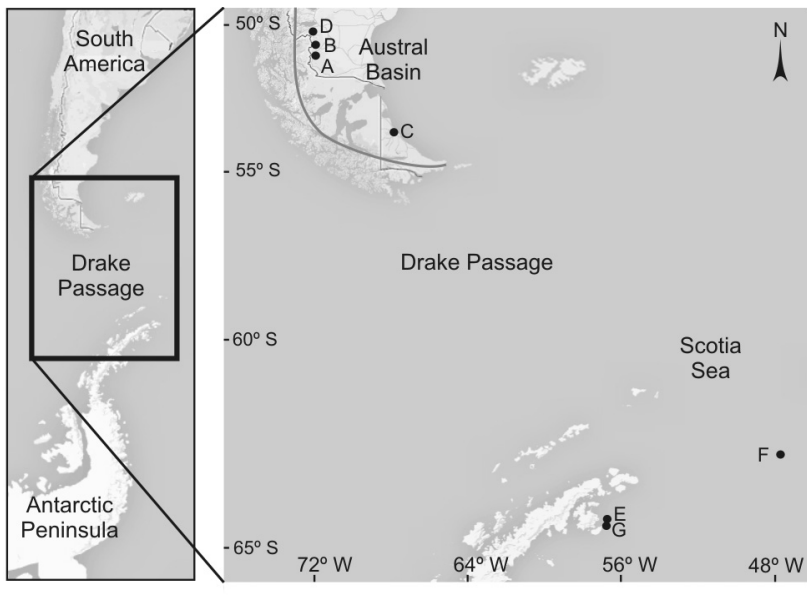

Figure 1. South America and Antarctic Peninsula map, indicating present-day location of the studied sections: A, Upper member Río Turbio Fm. (González Estebenet, 2014); B, Upper member Río Turbio Fm. (Archangelsky, 1969; Guerstein et al., 2014); C, Leticia Fm. in Río de la Turba section (Guerstein et al., 2008b); D, Man Aike Fm. (Guerstein et al., 2014); E, La Meseta Fm. (Cocozza and Clarke, 1992); F, Bruce Bank (Mao and Mohr, 1995); G, La Meseta Fm. (Wrenn and Hart, 1988). From Google Maps (https://maps.google.com.ar).

stratigraphic distribution provides a correlation tool that can be applied to other sites of the Southern Ocean.

In recent years, interest has grown in the progressive opening of the Southern Ocean Gateways. Bijl et al. (2013b) suggested an incipient opening of the Tasman Gateway with a consequent onset of surface water throughflow starting at about 50-49 Ma during the Ypresian (early Eocene). Regarding the Drake Passage, the time of its opening and

\section{TABLE 1. Published works considered in this study.}

\begin{tabular}{|c|c|c|c|c|}
\hline \multicolumn{2}{|c|}{ Lithostratigraphy } & \multirow{2}{*}{$\begin{array}{l}\text { Location } \\
\text { Santa Cruz, Austral Basin }\end{array}$} & \multirow{2}{*}{$\begin{array}{l}\text { Latitude and Longitude } \\
51^{\circ} 31^{\prime} 13^{\prime \prime S}, 72^{\circ} 15^{\prime} 11^{\prime \prime} \mathrm{W}\end{array}$} & \multirow{2}{*}{$\begin{array}{l}\text { Sources } \\
\text { González Estebenet et al., } 2014\end{array}$} \\
\hline$A$ & Upper member of the Río Turbio Fm. & & & \\
\hline$B$ & Upper member of the Río Turbio Fm. & Santa Cruz, Austral Basin & $\begin{array}{l}\text { three integrated cores } \\
50^{\circ} 45^{\prime} 14^{\prime \prime S}, 72^{\circ} 01^{\prime} 39^{\prime \prime} W ; \\
50^{\circ} 56^{\prime} 21^{\prime \prime} \mathrm{S}, 72^{\circ} 02^{\prime} 08^{\prime \prime} W ; \\
50^{\circ} 35^{\prime} 59^{\prime \prime} \mathrm{S}, 72^{\circ} 13^{\prime} 40^{\prime \prime} W\end{array}$ & $\begin{array}{l}\text { Archangelsky, } 1969 \\
\text { Guerstein et al., } 2014\end{array}$ \\
\hline C & Leticia Fm. & $\begin{array}{l}\text { Río de la Turba section. } \\
\text { Tierra del Fuego, Austral Basin }\end{array}$ & $53^{\circ} 58^{\prime} \mathrm{S}, 68^{\circ} 28^{\prime} W$ & Guerstein et al., $2008 b$ \\
\hline$D$ & Man Aike Fm. & Santa Cruz, Austral Basin & $50^{\circ} 21^{\prime} 45^{\prime \prime S}, 72^{\circ} 14^{\prime} 30^{\prime \prime} \mathrm{W}$ & Guerstein et al., 2014 \\
\hline$E$ & $\begin{array}{l}\text { La Meseta Fm. Associations } 2 \text { and } 3 \\
\text { (between } 43 \text { and } 165 \mathrm{~m} \text { ) }\end{array}$ & $\begin{array}{l}\text { Cape Wiman, Seymour Island, } \\
\text { Antarctic Peninsula }\end{array}$ & $64^{\circ} 13^{\prime} 5^{\prime \prime S}, 56^{\circ} 38^{\prime} \mathrm{W}$ & Cocozza and Clarke, 1992 \\
\hline$F$ & Core IO1578-59 in Bruce Bank & Scotia Sea, Antarctica & $60^{\circ} 33.6^{\prime} \mathrm{S}, 40^{\circ} 13.2^{\prime} \mathrm{W}$ & Mao and Mohr, 1995 \\
\hline$G$ & $\begin{array}{l}\text { La Meseta Fm. Section } 3 \text { (between } \\
47 \text { and } 188 \mathrm{~m} \text { ) }\end{array}$ & $\begin{array}{l}\text { Seymour Island, } \\
\text { Antarctic Peninsula }\end{array}$ & $64^{\circ} 14^{\prime} S, 56^{\circ} 49^{\prime} W^{*}$ & $\begin{array}{l}\text { Wrenn and Hart, } 1988 \\
\text { Douglas et al., } 2014\end{array}$ \\
\hline
\end{tabular}

* Geographical coordinates from Google Earth. 
TABLE 2. Taxonomic list of species of dinoflagellate cysts present in the localities A-G (see Table 1 for abbreviations).

\begin{tabular}{|c|c|c|c|c|c|c|c|c|}
\hline Species & Bioevents (Ma) & $A$ & B & C & $\boldsymbol{D}$ & $E$ & $\boldsymbol{F}$ & $\boldsymbol{G}$ \\
\hline Deflandrea antarctica Wilson, $1967 a^{*}$ & FO: $58.20( \pm 0.30)$ & $x$ & $x$ & $x$ & $x$ & $x$ & $x$ & $x$ \\
\hline Enneadocysta dictyostila (Menéndez) Fensome et al., 2006 * & $\begin{array}{l}\text { FCO: } 45.20( \pm 0.20) \\
L O: 33.40( \pm 0.30)\end{array}$ & $x$ & $x$ & $x$ & $x$ & $x$ & $x$ & $x$ \\
\hline Spinidinium $s p p .^{*}$ & & $x$ & $x$ & $x$ & $x$ & $x$ & $x$ & $x$ \\
\hline Enneadocysta brevistila Fensome et al., 2006 * & & $x$ & $x$ & $x$ & $x$ & $x$ & & \\
\hline Arachnodinium antarcticum Wilson and Clowes, 1982 * & $\begin{array}{l}\text { FO: } 48.70( \pm 0.20) \\
\text { LO: } 36( \pm 0.3)\end{array}$ & $x$ & $x$ & $x$ & & $x$ & $x$ & $x$ \\
\hline Vozzhennikovia apertura Wilson, $1967 a^{*}$ & $F O: 65.10( \pm 0.40)$ & $x$ & $x$ & $x$ & & $x$ & $x$ & $x$ \\
\hline Deflandrea cygniformis Pöthe de Baldis, 1966 * & & & & $x$ & & & $x$ & $x$ \\
\hline Octodinium askiniae Wrenn and Hart, 1988 * & FO: $53.90( \pm 0.10)$ & & & & & $x$ & $x$ & $x$ \\
\hline Thalassiphora pelagica (Eisenack) Eisenack and Gocht, 1960 & FO: $55.30( \pm 0.20)$ & $x$ & $x$ & $x$ & $x$ & $x$ & & \\
\hline Selenopemphix spp. & $F O: 49.50( \pm 0.30)$ & $x$ & $x$ & $x$ & $x$ & & & $x$ \\
\hline Hystrichosphaeridium truswelliae Wrenn and Hart, 1988 & $L O: 36( \pm 0.3)$ & $x$ & $x$ & $x$ & $x$ & & & $x$ \\
\hline Lejeunecysta $s p p$. & & $x$ & $x$ & $x$ & $x$ & & $x$ & \\
\hline Operculodinium centrocarpum (Deflandre and Cookson, 1955) Wall, 1967 & & $x$ & $x$ & $x$ & $x$ & & $x$ & \\
\hline Turbiosphaera filosa Wilson, $1967 a$ & & $x$ & $x$ & $x$ & & & & \\
\hline Achomosphaera $s p . A$ & & $x$ & & & $x$ & & & \\
\hline Hystrichosphaeridium tubiferum (Ehrenberg, 1838) Davey and Williams, 1966 & & & & $x$ & & & $x$ & \\
\hline Pyxidinopsis delicata Wilson, 1988 & & & & $x$ & & & $x$ & \\
\hline Palaeocystodinium $s p$. & & & & $x$ & & & & $x$ \\
\hline Alterbidinium $s p$ & & & $x$ & & & $x$ & $x$ & $x$ \\
\hline Impletosphaeridium clavus Wrenn and Hart, 1988 & & & & & & $x$ & $x$ & $x$ \\
\hline Phthanoperidinium stockmansii (de Coninck) Lentin and Williams, 1977 & & & & & & $x$ & $x$ & $x$ \\
\hline Impagidinium spp. & & $x$ & & & & $x$ & $x$ & $x$ \\
\hline Cordosphaeridium minimum (Morgenroth, 1966a) Benedek, 1972 & & & & & & $x$ & $x$ & \\
\hline Paucisphaeridium inversibuccinum (Davey and Williams, 1966) Bujak et al., 1980 & & & & & & $x$ & $x$ & \\
\hline Deflandrea spp. & & $x$ & & & & $x$ & $x$ & $x$ \\
\hline Operculodinium bergmannii (Archangelsky, 1969) Stover and Evitt, 1978 & & & & & & $x$ & $x$ & $x$ \\
\hline
\end{tabular}

Species classified as endemic or bipolar according to Bijl et al. $(2011,2013 a)$ and Houben et al. (2013) are indicated with asterisk (*). Magnetostratigraphically calibrated ages of key species refer to: $F O$, first occurrences; $F C O$, first common occurrences and LO, last occurrences.

deepening is still under discussion, with ages ranging from the early-middle Eocene (Livermore et al., 2005, 2007; Scher and Martin, 2006) to the early Miocene (Barker, 2001). Scher and Martin (2006), Livermore et al. (2007) and Lagabrielle et al. (2009) suggested an early opening for this passage, with shallow waterflows from the Pacific to the Atlantic Oceans. The aim of this review is to compare the middle Eocene dinoflagellate cyst assemblages from different localities of the Drake Passage area using multivariate data analysis and relate the results with the tectonic and paleoceanographic settings for the Drake Passage during this critical interval.

\section{MATERIALS AND METHODS}

We reviewed the published middle Eocene dinoflagellate cyst data drawn from assemblages dominated by Antarcticendemic species of sections from the Drake Passage area. We considered the following units for this analysis: (A) upper member of the Río Turbio Fm. studied in outcrop sections

Figure 2. Species from the Leticia Formation and the upper member of the Río Turbio Formation, Austral Basin. Specimens are identified by sample number/England Finder references. 1, Enneadocysta dictyostila, LE-RT-6/Q32. 2, Deflandrea antarctica, RT 12/1-9/P29/3. 3, Arachnodinium antarcticum, RT 12/1-4/N31/2; 4,Vozzhennikovia apertura, RT 14/1-1/P45/1. 5, Lejeunecysta sp., RT 13/1-1/H17/4; 6, Impagidinium parvireticulatum, RT 15/1-6/M45/2. 7, Selenopemphix nephroides, RT 15/1-6/L28. 8, Hystrichosphaeridium truswelliae, RT 13/1-3/H33. 9, Achomosphaera sp. A, RT13/1-3/J30/2. 10, Thalassiphora pelagica, RT 12/1-6/Z37. 11, Operculodinium centrocarpum, RT 12/1-9/X45. 12, Hystrichosphaeridium tubiferum, LE-RT-5/R49. Scale bar $=20 \mu \mathrm{m}$. 

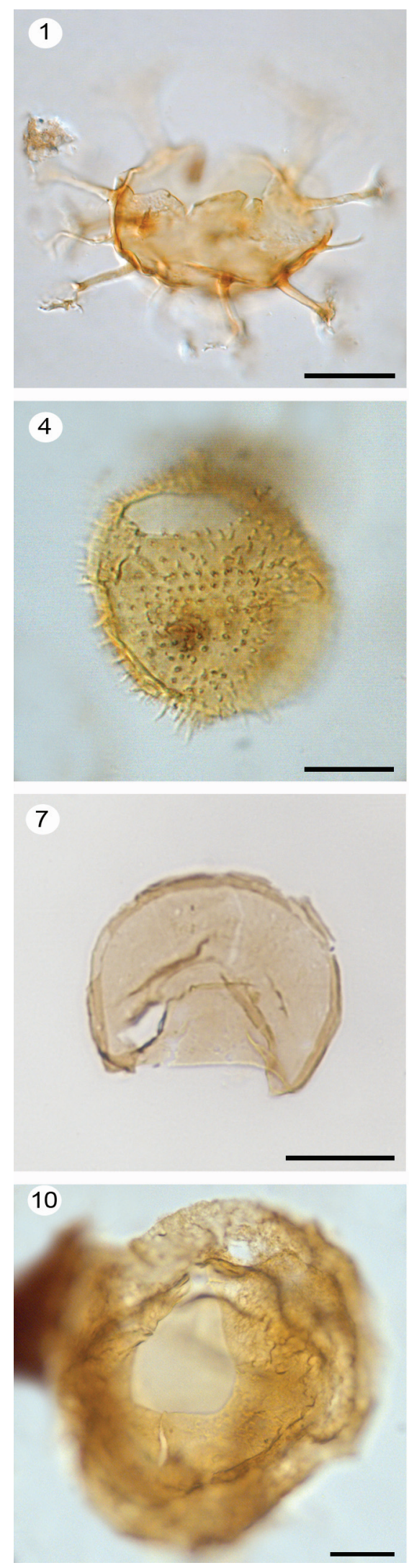

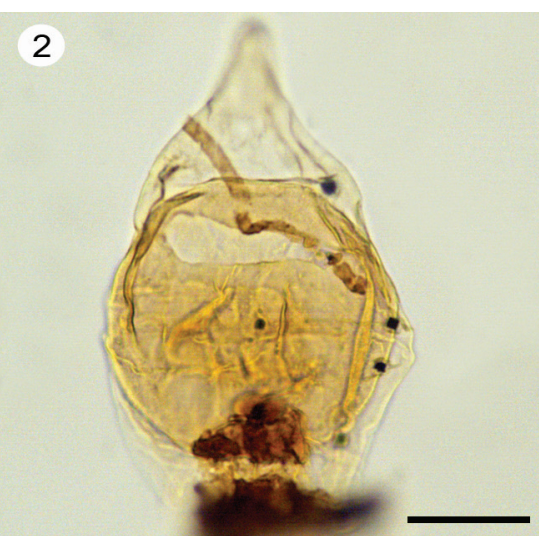

5
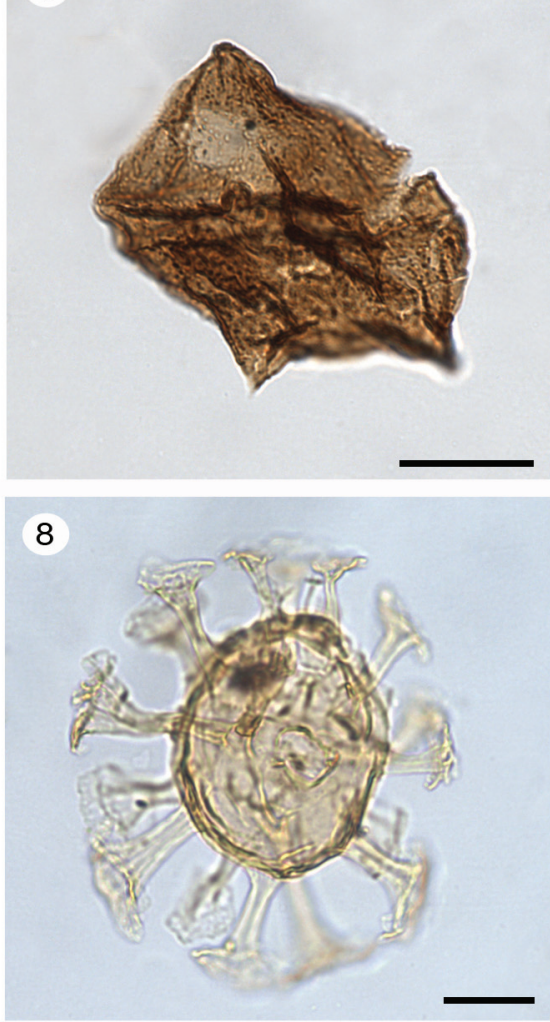

11
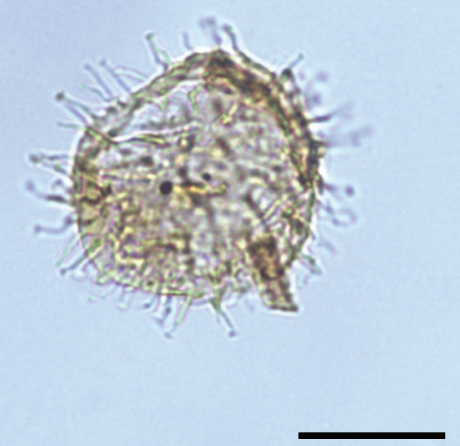

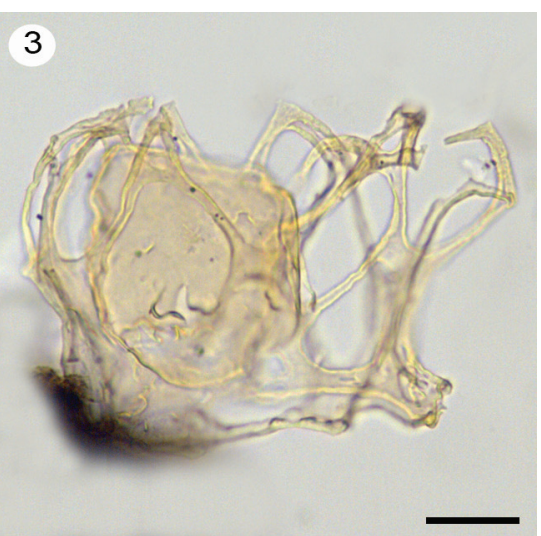

6
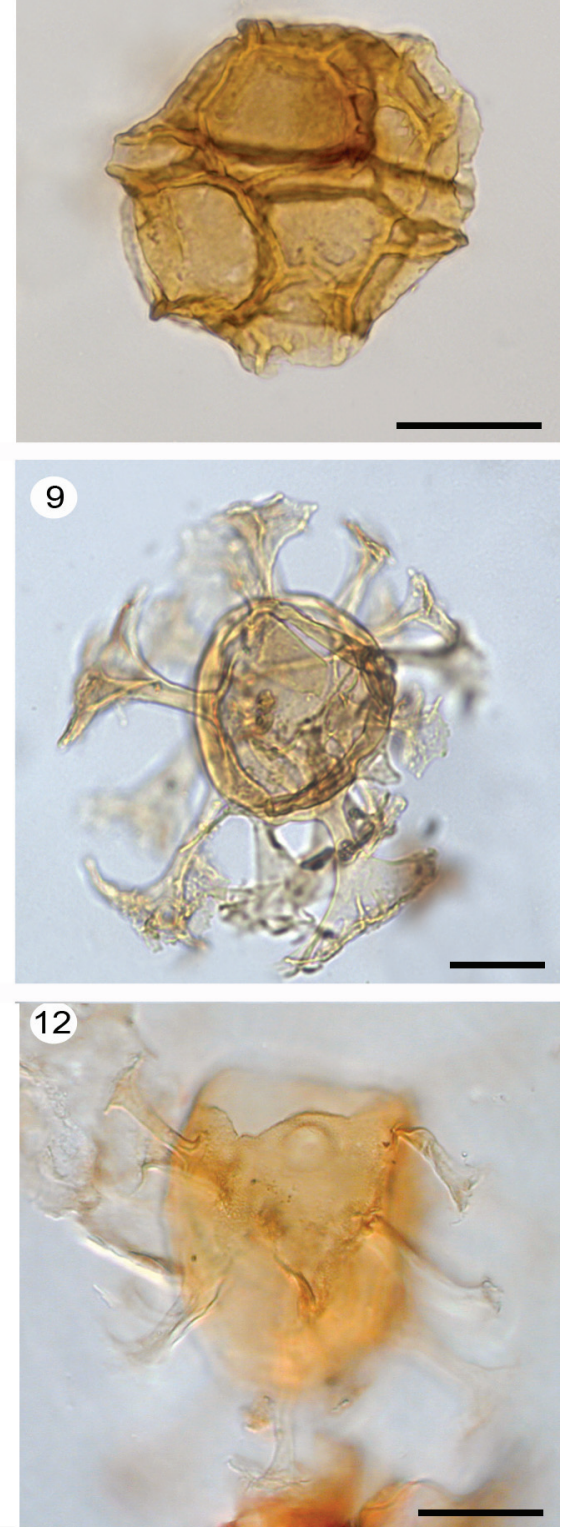
(González Estebenet et al., 2014); (B) upper member of the Río Turbio Formation in YCP coreholes (Archangelsky, 1969; Guerstein et al., 2014); (C) Leticia Fm. in Río de la Turba section (Guerstein et al., 2008b); (D) Man Aike Fm. (Guerstein et al., 2014); (E) La Meseta Fm. (Cocozza and Clarke, 1992); (F) Bruce Bank in core IO1578-59 (Mao and Mohr, 1995); (G) La Meseta Fm. (Wrenn and Hart, 1988; Douglas et al., 2014) (Fig. 1; Tab. 1).

The taxonomic updating of dinoflagellate cyst species recorded from each locality was based on Williams et al. (2004), Fensome et al. (2006, 2008) and Sluijs et al. (2009). Table 2 shows a presence-absence data list defined with the species that appeared in at least two localities, including their biogeographic distribution according to Bijl et al. (2011, 2013a) and Houben et al. (2013). The magneto-stratigraphically calibrated ages of the diagnostic species in the Southern Ocean are provided by First Occurrence datum (FO), First Common Occurrence data (FCO), Last Occurence datum (LO), including the South Pacific Dinocyst Zones (SPDZ) of Bijl et al. (2013a). In this work we selected the stratigraphic interval above the FCO of Enneadocysta dictyostila (Menéndez) Fensome et al., 2006 in each locality. This dinoflagellate event represents the basis of Zone SPDZ11 of Bijl et al. (2013b) dated at $45.2 \mathrm{Ma}$ (middle Lutetian). The youngest age of the analyzed sections is determined by the LO data of Arachnodinium antarcticum and/or Hystrichosphaeridium truswelliae at $36 \mathrm{Ma}$ in Zone SPDZ13 (Bartonian-Priabonian, 40.0 Ma-35.95 Ma). A similar biostratigraphic age model was applied by Douglas et al. (2014) for La Meseta Formation in Seymour Island. These authors considered that this formation was deposited between 45 and $34 \mathrm{Ma}$ based on the FO of Enneadocysta dictyostila and the abundance of other Antarctic-endemic dinoflagellate cyst species, in contrast with previous early to late Eocene age assignments (Wrenn and Hart, 1988).

The palynological samples from the Leticia Formation and the upper member of the Río Turbio Formation were processed at the Museo Argentino de Ciencias Naturales, Bernardino Rivadavia, Buenos Aires, Argentina using hydrochloric and hydrofluoric acids. The residues were sieved through screens of 10, 25 and $180 \mu \mathrm{m}$ and stained with Bismarck C. Strew mounts were prepared with gelatin glycerin as a mounting medium. The slides are housed at the Laboratorio de Palinología, Instituto Geológico del Sur, Bahía Blanca, Argentina (LPUNS). Light microscopy observation

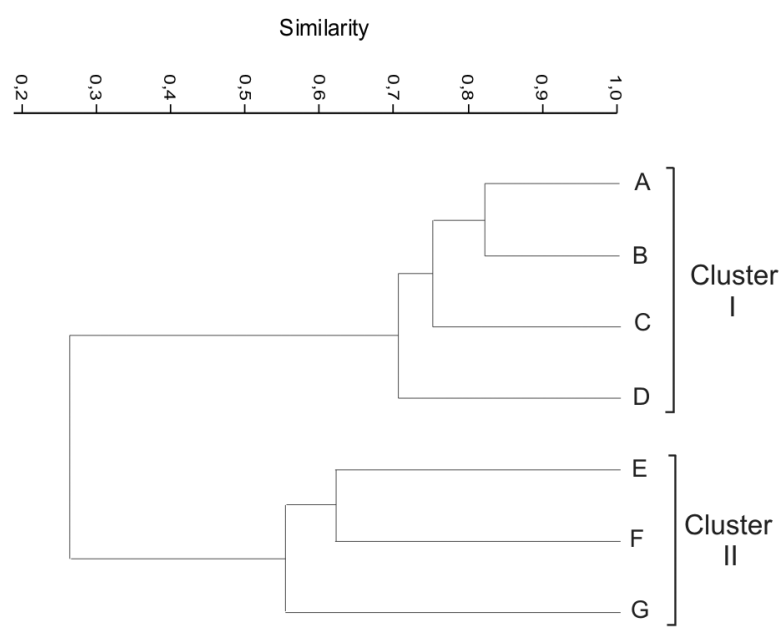

Figure 3. Dendrogram of localities based on non-endemic dinoflagellate cysts showing two clusters separated at 0.27 units of similarity. Cluster I comprised localities from the Austral Basin (A-D). Cluster II involves the localities from Antarctic Peninsula and Scotia Sea (E-G). For localities abbreviations see Table 1. Dendrogram obtained using the Unweighted Pair Group Method (UPGMA) and Dice index to compare similarities.

was carried out using a Nikon Eclipse 600 microscope and an attached Micrometrics high-resolution digital camera. Most of the species recorded in the Austral Basin are illustrated in Figure 2. Sample and slide number with England Finder (EF) references are provided for each illustrated specimen.

In order to visualize the differences among the dinoflagellate cyst assemblages from the localities compared we analyzed only the distribution of non-endemic taxa. The endemic species were recorded in all the tested sites since their consistent presence was the requirement to select the units for the comparison. Cluster analyses were carried out on both the localities and the species present in these sites using the Unweighted Pair Group Method (UPGMA) and Dice similarity index. Statistical analyses and charts were performed using PAST, version 2.17 (Hammer et al., 2001).

\section{RESULTS}

The dendrogram based on the localities (Fig. 3) allows distinguishing two clusters separated at 0.27 units of similarity. Cluster I ( 0.71 units of similarity) is defined by the localities from the Austral Basin (localities A, B, C and D), and cluster II (0.56 units of similarity) comprises the localities from Antarctic Peninsula and Scotia Sea (localities E, F and G). Fig. 4 illustrates the results of the cluster analysis based on non-endemic species. The dendrogram defines two clusters 


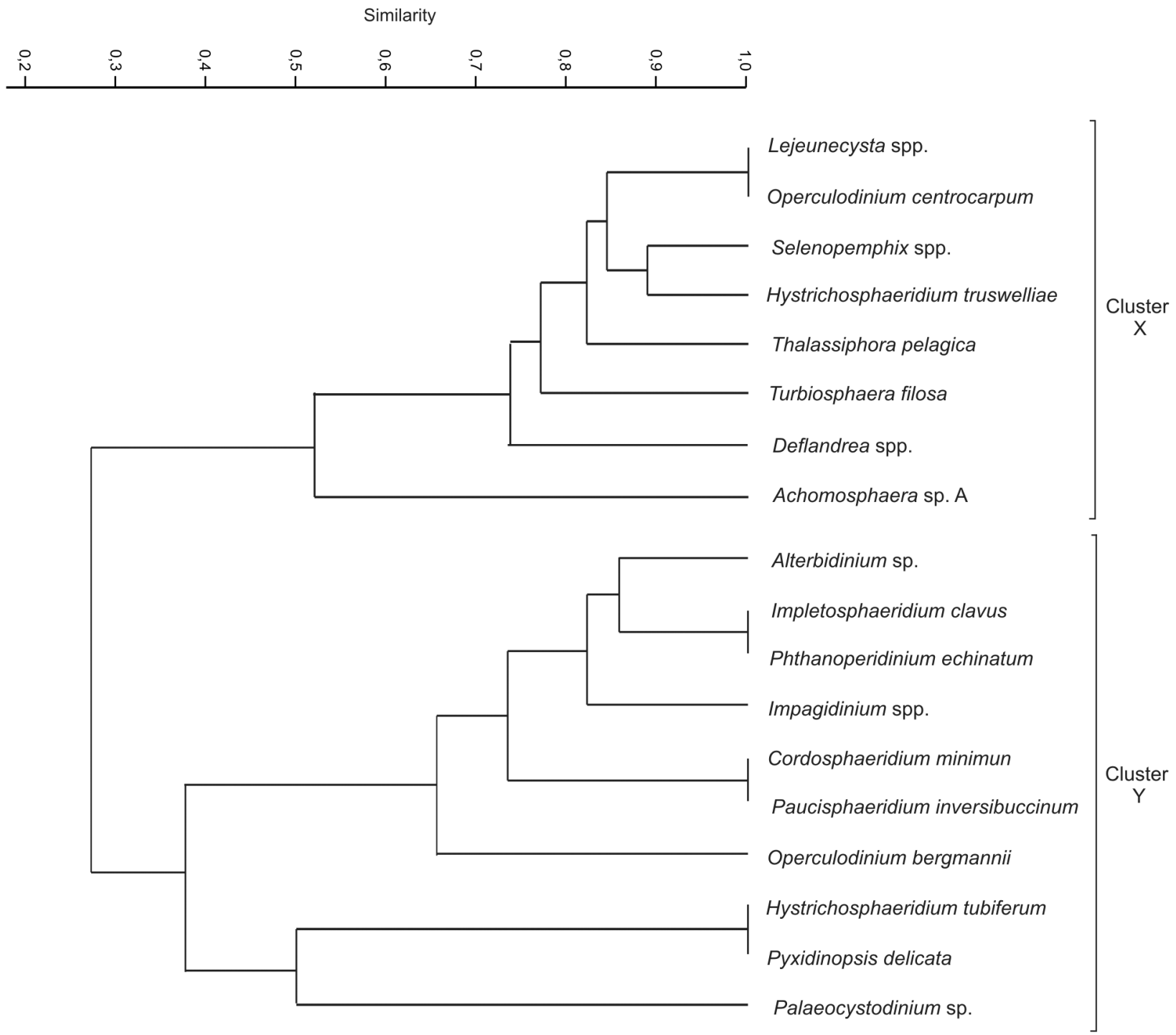

Figure 4. Dendrogram of the non-endemic dinoflagellate cysts showing two clusters (X and $Y$ ) separated by 0.27 units of similarity. Dendrogram obtained using the Unweighted Pair Group Method (UPGMA) and Dice similarity index.

separated at 0.27 units of similarity. Cluster X includes Deflandrea spp., Lejeunecysta spp., Operculodinium centrocarpum, Selenopemphix spp., Thalassiphora pelagica, Turbiosphaera filosa, Achomosphaera sp. A, and Hystrichosphaeridium truswelliae. Cluster Y is defined by Alterbidinium sp., Cordosphaeridium minimun, Hystrichosphaeridium tubiferum, Impagidinium spp., Impletosphaeridium clavus, Operculodinium bergmannii, Palaeocystodinium sp., Paucisphaeridium inversibuccinum, Phthanoperidinium echinatum and Pyxidinopsis delicata. Figure 5 depicts the results of a two-way cluster analysis indicating the relationship between taxa and sites based on the dendrograms represented in Figs. 3 and 4. The result emphasizes that cluster I (including the localities from the Austral Basin; Fig. 3) comprises the species from cluster $\mathrm{X}$ (Fig. 4), and cluster II (comprising the localities from the Antarctic Peninsula and Scotia Sea; Fig. 3) is represented by the species of cluster Y (Fig. 4).

\section{DISCUSSION}

The palaeogeographic distribution of dinoflagellate cyst assemblages in the areas surrounding the Drake Passage shows the conspicuous presence of the Antarctic-endemic assemblage components. Although, the statistical analysis based on nonendemic taxa exhibited a clear difference between the locali- 


\author{
Species \\ Lejeunecysta spp. \\ Operculodinium centrocarpum \\ Selenopemphix spp. \\ Hystrichosphaeridium truswelliae \\ Thalassiphora pelagica \\ Turbiosphaera filosa \\ Deflandrea spp. \\ Achomosphaera sp. A \\ Alterbidinium sp. \\ Impletosphaeridium clavus \\ Phthanoperidinium echinatum \\ Impagidinium spp. \\ Cordosphaeridium minimun \\ Paucisphaeridium inversibuccinum \\ Operculodinium bergmannii \\ Hystrichosphaeridium tubiferum \\ Pyxidinopsis delicata \\ Palaeocystodinium sp.
}

Figure 5. Two-way cluster analyses of dinoflagellate cyst species and localities. Localities and species are arranged following the dendrograms in Figures 2 and 3 . Species present in each locality are indicated with black squares.

ties to the north (Austral Basin) and south (Antarctic Peninsula and the Scotia Sea) of what today is the Drake Passage (Fig. 5). What palaeogeographic and palaeoceanographic configuration of the Drake Passage area could explain a broad distribution of the Antarctic-endemic assemblage, and at the same time a latitudinal differentiation based on non-endemic taxa?

Huber et al. (2004) proposed for the middle-late Eocene a surface ocean circulation model with extensive polar clockwise gyres (Fig. 6.1) and suggested that such gyres had generated a selective intrinsic mechanism called "cold trap", which led to the endemism of species tolerant to relatively low surface-water temperatures. Guerstein and Daners (2010) considered that the mechanism proposed for the South Pacific could be similarly applied to the South Atlantic and thus con- jectured the existence of the clockwise proto-Weddell Gyre (p-WG) equivalent to the proto-Ross Gyre (p-RG) (Fig. 6.1). Subsequently, this ocean circulation model was confirmed by circum-Antarctic dinoflagellate cyst biogeographic patterns (Bijl et al., 2011) that would explain the presence of the Antarctic-endemic assemblage in all the analysed localities.

Throughout the past decades, general studies have described the progressive openings of the Tasmanian Gateway and the Drake Passage. Based on data from the IODP cores from the Wilkes Land Margin (eastern Antarctica), Bijl et al. (2013b) analysed the organic geochemical biomarker data along with the dinoflagellate cysts records suggested a connection developed between the Pacific Ocean and the Australo-Antarctic Gulf about 49-50 Ma ago. This connection would have resulted in a shallow waterflow through the Tas- 


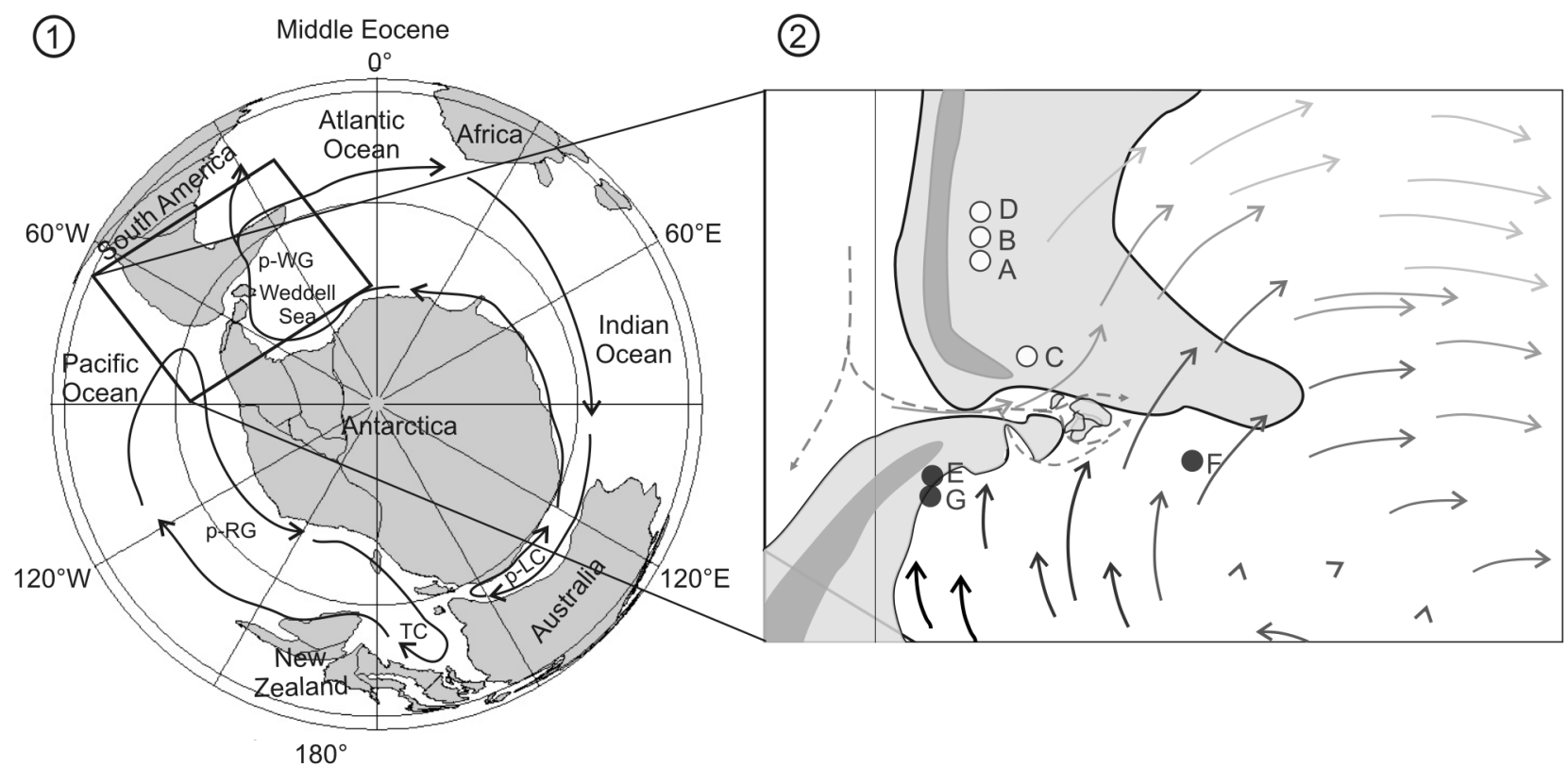

Figure 6. 1, Middle Eocene paleogeographic map derived from Plate Tectonic Reconstructions On-line Paleogeographic Mapper (Schettino and Scotese, 2005). Gray areas indicate continental crust. Black lines indicate schematic oceanic circulation (modified after Huber et al., 2004 and Guerstein and Daners, 2010). 2, Middle Eocene Paleogeographic configuration of the Drake Passage with location of the studied units (A-G, see Tab. 1). Light gray areas indicate continental crust; dark gray areas indicate the maximum of the middle Eocene marine transgression (after Livermore et al., 2007; Rodríguez Raising, 2010). Dash-line arrows indicate the shallow water flow from the Pacific Ocean to the Atlantic Ocean through an incipient opening of the Drake Passage (modified from Livermore et al., 2007). Full-line arrows represent the western part of the p-WG (after Huber et al., 2004; Warnaar 2006 and Thomas, 2006). The darkest arrows represent the lowermost surface water temperatures. Abbreviations: p-WG, proto-Weddell Gyre; p-RG, proto-Ross Gyre; TC, Tasman Current; p-LC, proto-Leeuwin Current.

man Gateway 17 Ma earlier than the deepening of the Drake Passage. These authors interpreted that the current westward flow would have induced surface-water cooling along the Antarctic coast during the middle Eocene.

Livermore et al. (2005, 2007) and Eagles et al. (2006), based on magnetic anomaly profiles adjacent to the South American margin and in the southwest Scotia Sea, proposed the subsidence on the continental shelves at the beginning of the middle Eocene ( $-50 \mathrm{Ma})$. This subsidence could have developed an ocean passage characterized by shallow ocean connections between the Pacific and Atlantic oceans (Livermore et al., 2007 figs. 2b-c). The shallow flows could have established a barrier for the continental fauna and might be probably responsible for the endemism of Eocene marsupials from La Meseta Formation on Seymour Island (Reguero et al., 2002). Eagles et al. (2006) and Livermore et al. (2007) proposed at $-41 \mathrm{Ma}$, the development of two relatively deepwater gaps together with restricted current flows of shallow waters. This hypothesis is enhanced by the study of Scher and
Martin (2006), who suggested that the influx of shallow Pacific waters into the South Atlantic Ocean started at approximately $41 \mathrm{Ma}$, based on shifts of neodymium isotope ratios from fossil fish teeth in drill cores.

Considering the previous hypothesis on the tectonic evolution of the Drake Passage, the differences between the nonendemic dinoflagellate cysts in the localities of the Austral Basin and western of Antarctica might be influenced by surface waters from different sources. The sites located to the south of the Drake Passage (Antarctic Peninsula and Scotia Sea) would reflect the influx of surface waters originated in Antarctic coasts and directed to the North through the p-WG. Otherwise, the shallow flows through the incipient opening of the Drake Passage -as proposed by Scher and Martin (2006) and Livermore et al. (2007)- would have allowed the input of waters with cosmopolitan taxa from the Pacific to the Atlantic Ocean. These taxa would have been subsequently transported together with the Antarctic-endemic components into the Austral Basin by the northwestern sector of the p-WG (Fig. 6.2). 


\section{CONCLUSIONS}

The dinoflagellate cyst distribution in the Southern Ocean has proven to be a powerful tool in reconstructing surface circulation patterns during the Paleogene and their modifications as a consequence of tectonic changes (Huber et al., 2004; Stickley et al., 2004; Bijl et al., 2013b). In this work, we apply the analysis of middle Eocene dinoflagellate cyst assemblages from different localities close to the Drake Passage to test the hypothesis proposed by Scher and Martin (2006) and Livermore et al. (2007) about the onset of shallow connections between the Pacific and Atlantic oceans through an incipient Drake Passage during this interval.

The comparison of dinoflagellate cyst assemblages in the Drake Passage area shows a broad distribution of the Antarctic-endemic assemblage typical of the middle Eocene. However, a cluster analysis points out a pronounced difference between the non-endemic species from localities to the north (Austral Basin) and south (Antarctic Peninsula and the Scotia Sea) of what is nowadays the Drake Passage. We propose that the assemblages in the Antarctic Peninsula and the Scotia Sea reflect the influence of Antarctic surface waters conducted by the p-WG, while the dinoflagellate cyst assemblages from the Austral Basin may be the result of the confluence of Pacific water flows through an incipient Drake Passage and Antarctic waters transported northwards by the northwestern part of the p-WG. Thus, the palaeogeographic distribution of dinoflagellate cysts reinforces the hypothesis of an early opening of the Drake Passage during the middle Eocene.

\section{ACKNOWLEDGEMENTS}

The authors thank V. Bowman and P. Bijl for their constructive reviews and valuable suggestions that greatly improved this manuscript. The samples from the Austral Basin studied by MSGE and GRG were processed by O. Cárdenas. The present work was funded by projects granted by Agencia Nacional de Promoción Científica y Tecnológica (PICT 89/09), Consejo Nacional de Investigaciones Científicas y Técnicas (PIP: 112-201101-00566) and Universidad Nacional del Sur (PGI 24/H125).

\section{REFERENCES}

Archangelsky, S. 1969. Estudio del paleomicroplancton de la Formación Río Turbio (Eoceno), Provincia de Santa Cruz. Ameghiniana 6: 181-218.

Barker, P.F. 2001. Scotia Sea regional tectonic evolution: implications for mantle flow and palaeocirculation. Earth-Science Reviews 55: 1-39.

Benedek, P.N. 1972. Phytoplanktonten aus dem Mittel- und Oberoligozän von Tönisberg (Niederrheingebiet). Palaeontographica, Abteilung B 137: $1-71$.

Bijl, P.K., Pross, J., Warnaar, J., Stickley, C.E., Huber, M., Guerstein, R., Houben, A.J.P., Sluijs, A., Visscher, H., and Brinkhuis, H. 2011. Environmental forcings of Paleogene Southern Ocean dinoflagellate biogeography. Paleoceanography 26: PA1202.

Bijl, P.K., Sluijs, A., and Brinkhuis, H. 2013a. A magneto-and chemostrati- graphically calibrated dinoflagellate cyst zonation of the early Palaeogene South Pacific Ocean. Earth-Science Reviews 124: 1-31.

Bijl, P.K., Bendle J.A.P, Bohaty S.M., Pross J., Schouten S., Tauxe L., Stickley, C.E., McKay, R.M., Röhl, U., Olney, M., Sluijs, A., Escutia, C., Brinkhuis, H., and Expedition 318 Scientists. 2013b. Eocene cooling linked to early flow across the Tasmanian Gateway. Proceedings of the National Academy of Sciences 110: 9645-9650.

Bujak, J.P., Downie, C., Eaton, G.L., and Williams, G.L. 1980. Dinoflagellate cysts and acritarchs from the Eocene of southern England. Special Papers in Palaeontology 24: 1-104.

Cocozza, C.D., and Clarke, C.M. 1992. Eocene microplankton from La Meseta Formation, northern Seymour Island. Antarctic Science 4: 355362.

Davey, R.J., and Williams, G.L. 1966b. V. The genus Hystrichosphaeridium and its allies. In: R.J. Davey, C. Downie, W.A.S. Sarjeant, and G.L. Williams, Studies on Mesozoic and Cainozoic dinoflagellate cysts; British Museum (Natural History) Geology, Bulletin, Supplement 3, p. 53-106.

Deflandre, G., and Cookson, I.C. 1955: Fossil microplankton from Australian Late Mesozoic and Tertiary sediments. Australian Journal of Marine and Freshwater Research 6: 242-313.

Douglas, P.M., Affek, H.P., Ivany, L.C., Houben, A.J., Sijp, W.P., Sluijs, A., Schouten, S., and Pagani, M. 2014. Pronounced zonal heterogeneity in Eocene southern high-latitude sea surface temperatures. Proceedings of the National Academy of Sciences 111: 6582-6587.

Eagles, G., Livermore, R., and Morris, P. (2006). Small basins in the Scotia Sea: the Eocene Drake passage gateway. Earth and Planetary Science Letters 242: 343-353.

Ehrenberg, C.G. 1838. Über das Massenverhältniss der jetzt lebenden KieselInfusorien und über ein neues Infusorien-Conglomerat als Polierschiefer von Jastraba in Ungarn. Königlich Akademie der Wissenschaften zu Berlin 1: $109-135$.

Eisenack, A., and Gocht, H. 1960. Neue Namen für einige Hystrichosphären der Bernsteinformation Ostpreussens. Neues Jahrbuch für Geologie und Paläontologie, Monatshefte 11:511-518.

Fensome, R.A., Guerstein, G.R., and Williams, G.L. 2006. The Paleogene dinoflagellate cyst genera Enneadocysta and Licracysta gen. nov.: new insights based on material from offshore eastern Canada and the Southern Hemisphere. Micropaleontology 52: 385-410.

Fensome, R.A., MacRae, R.A., and Williams, G.L. 2008. DINOFLAJ2, Version 1. American Association of Stratigraphic Palynologists, Data Series no. 1.

González Estebenet, M.S., Guerstein, G.R., and Rodriguez Raising, M.E. 2014. Middle Eocene Dinoflagellate cysts from Santa Cruz Province, Argentina: Biostratigraphy and Paleoenvironment. Review of Palaeobotany and Palynology http://dx.doi.org/10.1016/j.revpalbo.2014.09.002

Guerstein, G.R. and Daners, G. 2010. Distribución de Enneadocysta (Dinoflagellata) en el Paleógeno del Atlántico Sudoccidental: implicancias paleoceanográficas. Ameghiniana 47: 461-478.

Guerstein, G.R., Brinkhuis, H., and Daners, G. 2008a. Eocene circulation and dinoflagellate distribution in the Southwestern Atlanctic Ocean. XII Reunión Argentina de Sedimentologia (Buenos Aires), Resúmentes: 81.

Guerstein, G.R., Guler, M.V., Williams, G.L., Fensome, R.A., and Chiesa, J.O. 2008b. Mid Palaeogene dinoflagellate cysts from Tierra del Fuego, Argentina: biostratigraphy and palaeoenvironments. Journal of Micropalaeontology 27: 75-94.

Guerstein, G.R., Guler, M.V., Brinkhuis, H., and Warnaar, J. 2010. Mid Cenozoic Palaeoclimatic and Palaeoceanographic trends in the Southwest Atlantic Basins, a Dinoflagellateview. The Paleontology of Gran Barranca. En: R.H. Madden, A.A. Carlini, M.G. Vucetich, R.F. Kay (Eds.), The Paleontology of Gran Barranca: Evolution and Environmental Change through the Middle Cenozoic of Patagonia. Cambridge, University Press, Cambridge p. 398-409.

Guerstein, G.R., González Estebenet, M.S., Alperin M.I., Casadío S.A., and Archangelsky, S. 2014. Correlation and paleoenvironments of middle Paleogene marine beds based on dinoflagellate cysts in southwestern Patagonia, Argentina. Journal of South American Earth Sciences 52: 166178.

Hammer, Ø., Harper, D.A.T., and Ryan, P.D. 2001. PAST: Paleontological Statistics Software Package for Education and Data Analysis. Palaeonto- 
logía Electronica 4: article 4. http://palaeo-electronica.org/2001_1/past/ issue1_01.htm

Houben, A.J.P., Bijl, P.K., Guerstein, R.G., Sluijs, A., and Brinkhuis, H. 2011. Malvinia escutiana, a new biostratigraphically important Oligocene dinoflagellate cyst from the Southern Ocean. Review of Palaeobotany and Palynology 165: 3-4.

Houben, A.J., Bijl, P.K., Pross, J., Bohaty, S.M., Passchier, S., Stickley, C.E., Röhl, U., Sugisaki, S., Tauxe, L., Flierdt, T., Olney, M., Sangiorgi, F., Sluijs, A., Escutia, C., Brinkhuis, H., and Expedition 318 Scientists. 2013. Reorganization of Southern Ocean plankton ecosystem at the onset of Antarctic glaciation. Science 340: 341-344.

Huber, M., Brinkhuis, H., Stickley, C.E., Döös, K., Sluijs, A., Warnaar, J., Schellenberg, S.A., and Williams, G.L. 2004. Eocene circulation of the Southern Ocean: Was Antarctica kept warm by subtropical waters? Paleoceanography 19: PA4026.

Lagabrielle, Y., Goddéris, Y., Donnadieu, Y., Malavieille, J., and Suarez, M. 2009. The tectonic history of Drake Passage and its possible impacts on global climate. Earth and Planetary Science Letters 279: 197-211.

Lentin, J.K., and Williams, G.L. 1977b. Fossil dinoflagellates: index to genera and species, 1977 edition. Bedford Institute of Oceanography, BI-R-77-8.

Lentin, J.K., and Williams, G.L. 1980. Dinoflagellate provincialism with emphasis on Campanian peridiniaceans. Contribution Series-American Association of Stratigraphic Palynologists 7: 1-47.

Livermore, R., Nankivell, A., Eagles, G., and Morris, P. 2005. Paleogene opening of Drake Passage. Earth Planetary Science Letters 236: 459-470.

Livermore, R., Hillenbrand, C.D., Meredith, M., and Eagles, G. 2007. Drake Passage and Cenozoic climate: An open and shut case? Geochemistry Geophysics Geosystems 8(1) Q01005.

Mao, S., and Mohr, B.A.R. 1995. Middle Eocene dinocysts from Bruce Bank (Scotia Sea, Antarctica) and their paleoenvironmental and paleogeographic implications. Review of Palaeobotany and Palynology 86: 235263.

Morgenroth, P. 1966a. Mikrofossilien und Konkretionen des nordwesteuropäischen Untereozäns. Palaeontographica, Abteilung B 119: 1-53.

Pöthe de Baldis, E.D. 1966. Microplancton del Terciario de Tierra del Fuego. Ameghiniana 4: 219-228.

Reguero, M.A., Marenssi, S.A., and Santillana, S.N. 2002. Antarctic Peninsula and South America (Patagonia) Paleogene terrestrial faunas and environments: biogeographic relationships. Palaeogeography, Palaeoclimatology, Palaeoecology 179: 189-210.

Rodríguez Raising, M.E. 2010. [Estratigrafía secuencial de los depósitos marinos y continentales del Eoceno-Oligoceno temprano de la cuenca Austral, suroeste de la provincia de Santa Cruz. Ph.D. Thesis, Universidad Nacional del Sur, Argentina, 203 p. Unpublished.].

Scher, H.D., and Martin, E.E. 2006. Timing and climatic consequences of the opening of Drake Passage. Science 312: 428-430.

Schettino, A., and Scotese, C.R. 2005. Apparent polar wander paths for the major continents (200 Ma-Present Day): A paleomagnetic reference frame for global plate tectonic reconstructions. Geophysical Journal International 163: 727-759.

Sluijs, A., Brinkhuis, H., Stickley, C.E., Warnaar, J., Williams, G.L., and Fuller, M. 2003. Dinoflagellate cysts from the Eocene/Oligocene transition in the Southern Ocean; results from ODP Leg 189. En: N.F. Exon, J.P. Kennett, M.J. Malone (Eds.), Proceedings of the Ocean Drilling Program, Scientific Results 189: 1-42.

Sluijs, A., Pross, J., and Brinkhuis, H. 2005. From greenhouse to icehouse; organic-walled dinoflagellate cysts as paleoenvironmental indicators in the Paleogene. Earth Science Reviews 68: 281-315.
Sluijs, A., Brinkhuis, H., Williams, G.L., and Fensome, R.A. 2009. Taxonomic revision of some Cretaceous-Cenozoic spiny organic-walled peridiniacean dinoflagellate cysts. Review of Palaeobotany and Palynology 154: 34-53

Stickley, C.E., Brinkhuis, H., Schellenberg, S.A., Sluijs, A., Röhl, U., Fuller, M., Grauert, M., Huber, M., Warnaar, J., and Williams, G.L. 2004. Timing and nature of the deepening of the Tasmanian Gateway. Paleoceanography 19: PA4027

Stover, L.E., and Evitt, W.R. 1978. Analyses of pre-Pleistocene organic-walled dinoflagellates. Stanford University Publications, Geological Sciences 15, $300 \mathrm{p}$.

Thomas, E. 2006. An ocean view of the early Cenozoic Greenhouse World. Oceanography 19: 94-103.

Vandenberghe, N., Speijer, R.P., and Hilgen, F.J. 2012. The Paleogene period. In: F.M. Gradstein, J.G. Ogg, M. Schmitz, G. Ogg, (Eds.), The Geologic Time Scale 2012, Elsevier 855-922.

Wall, D. 1967. Fossil microplankton in deep-sea cores from the Caribbean Sea. Palaeontology 10: 95-123.

Warnaar, J. 2006. [Climatological implications of Australian-Antarctic separation. PhD Thesis, Utrecht University, Utrecht, Netherlands, 143 p. Unpublished].

Williams, G.L., Brinkhuis, H., Pearce, M.A., Fensome, R.A., and Weegink, J.W., 2004. Southern Ocean and global dinoflagellates cyst events compared; index events for the late Cretaceous-Neogene. In: N.F. Exon, J.P. Kennett, and M.J. Malone (Eds.), Proceedings of the Ocean Drilling Program. Scientific Results 189: 1-98. odp.tamu.edu/publications/189_SR/ $107 / 107$.

Wilson, G.J. 1967a. Some new species of Lower Tertiary dinoflagellates from McMurdo Sound, Antarctica. New Zealand Journal of Botany 5: 57-83.

Wilson, G.J. 1988. Paleocene and Eocene dinoflagellate cysts from Waipawa, Hawkes Bay, New Zealand. New Zealand Geological Survey Paleontological Bulletin 57.

Wilson, G.J., and Clowes, C.D. 1982. Arachnodinium, a new dinoflagellate genus from the Lower Tertiary of Antarctica. Palynology 6: 97-103

Wrenn, J.H., and Beckman, S.W. 1982. Maceral, total organic carbon, and palynological analyses of Ross Ice Shelf Project site J9 cores. Science 216: $187-189$.

Wrenn, J.H., and Hart, G.F. 1988. Paleogene Dinoflagellate Cyst Biostratigraphy of Seymore Island, Antarctica. In: R.M. Feldmann, and M.O. Woodburne, (Eds.), Geology and Paleontology of Seymour Island, Antarctic Peninsula. Memoirs of the Geological Society of America 169: 321447

doi: 10.5710/AMGH.06.08.2014.2727

Recibido: 31 de marzo de 2014

Aceptado: 06 de agosto de 2014 